International Journal of Economics, Business and Accounting Research (IJEBAR)

Peer Reviewed - International Journal

Vol-4, Issue-2, 2020 (IJEBAR)

E-ISSN: 2614-1280 P-ISSN 2622-4771

https://jurnal.stie-aas.ac.id/index.php/IJEBAR

\title{
CURRENT STATE AND PROJECTIONS OF THE MARITIME TRANSPORT SECTOR FOR ECONOMIC DEVELOPMENT IN IRAQ
}

\author{
Adnan Farhan Aljawareen (Ph.D.) \\ University of Basrah- Iraq \\ E-mail:adnan352000@yahoo.com
}

\begin{abstract}
The transportation sector plays a critical role in balanced economic and regional development, as well as affording a great deal of influence on national integration into the world economic market. This paper studies current trends in the maritime sector in Iraq and presents some recommendations to improve maritime transport and ports' efficiency in order to enhance economic development. Various problems and obstacles faced by the ports of Iraq, which have piled up during the last three decades, acted as a major setback in its underdevelopment and weakened its functional capacity, and limited its role in economic development. Therefore, the government should formulate policies that would encourage foreign and private participations in the maritime sector of the economy.
\end{abstract}

Keywords: $\quad$ Maritime sector-Transport-Economic development- Ports.

JEL: L91- R42- O18

\section{Introduction}

Over the last five decades, maritime transport has developed tremendously changing the shape of the world economy. Between 1950 and 1995 transportation grew from (0.55) billion tonnes to (4.3) billion tonnes (Stopford, 1997), and in 2011 it continued and reached (8.7) billion tonnes (United Nations Conference on Trade and Development - Recent developments and trends in international maritime transport affecting trade of developing countries, 2013). This led the maritime industry to become one of the fastest growing economic sectors post second world war economy and ports to become an essential means of integration into the global economy.

The transportation sector is one of the sectors included in the economic structure of any country including, the economic development of any country and is directly linked to the development of transportation sector. The main role of transport system, in general, is to allow the flow of people and goods. Moreover, the importance of the maritime industry is rising continuously, therefore, the maritime sector increasingly plays a vital role in the development of port cities and communities in coastal refions, contributing to their well-being and prosperity. One of the most studied determinant factors of transport cost is geography, especially distance. When the distance between ports and inlands lengths is higher, costs are likely to increase, and vice versa.

The Iraqi maritime sector has faced many disruptive circumstances, such as the Iraq-Iran war (1980-1988), first Gulf war in 1991, economic sanctions (1991-2003), and second Gulf war in 2003. Moreover, after 2003, corruption negatively affected productivity, efficiency and its share in the development of the Iraqi economy leading to decline. The objective of this paper is to analyze the current status of the maritime sector in Iraq and to clarify the main challenges in order to improve its efficiency. This paper tries to answer two questions, the first being: is there is a vital role for Iraqi ports in the economy? and secondly: what are the main obstacles facing the Iraqi maritime sector? The paper is divided into four main parts. The purpose of the next part of the paper is to highlight the literature review of maritime transport and its impact on economic development. The third section concentrates on the

Page 96 International Journal of Economics, Business and Accounting Research (IJEBAR) 
International Journal of Economics, Business and Accounting Research (IJEBAR)

Peer Reviewed - International Journal

Vol-4, Issue-2, 2020 (IJEBAR)

E-ISSN: 2614-1280 P-ISSN 2622-4771

https://jurnal.stie-aas.ac.id/index.php/IJEBAR

overview of the Iraqi maritime sector and the fourth section explains the main challenges facing the Iraqi maritime sector. The final section is related to the future of the Iraqi maritime sector.

\section{Literature Review}

Maritime transport, which is also called "waterborne transport" or "seaborne transport" is an important, strategic industry, which has an impact on the economies of countries bordering the sea. Therefore, states attach great care and engage in mobilizing activities in various ways to stimulate international trade and garner advantages from this crucial sector.

The need for port usage is a demand derived from import, export and transshipment, because people and sectors exchange goods that are grown and consumed at different positions.

OECD indicates that enhanced efficiency of ports decreases the costs of trade, increases the value added, creates fresh businesses and attract certain economic sectors(Merk, 2010). If cities wish to benefit, then these ports should be competitive which can be achieved by strengthening maritime links, port operations, and hinterland connections. Local goodwill for port functions in cities is essential and can be gained. Carlo Cippola(Cipolla, 1978) suggests that the transport industry has been one of the most important factors responsible for shifting the world from an essentially national system to the global economy that exists today. Fast and cheap transport was one of the main products of the Industrial Revolution. Distances were shortened at an astonishing pace. Day by day the world seems smaller and societies that for millennia practically ignored each other are suddenly put in contact or conflict (Stopford, 1997).

Indicators of effective ports are broken down, as follows.

Several indicators can be used to measure the effectiveness and productivity of ports, but because data is not usually publicly available but accessed through port authorities and operators, the following indicators which were used by the World Bank will be used to measure the effectiveness and productivity of Iraqi ports(The World Bank, 2016b):

1. The efficiency of customs and border management clearance.

2. The quality of trade and transport infrastructure

3. The ease of arranging competitively priced shipments

4. The competence and quality of logistics services

5. The ability to track and trace consignments

6. The frequency at which shipments reach consignees within scheduled or expected delivery times.

To measure the economic impacts of the maritime sector on economic development common factors considered include the quantity of jobs, sales, output or revenue and tax receipts associated with an activity (Dwarakish \& Salim, 2015). The role of ports on the development of a nation as a part of transportation services is examined by Berköz and Tekba (1999) by using regression analysis. In this model, Gross National Income is taken as the dependent variable, while port length, total traffic figures, imports and exports, ship visits, number of workers and storage/warehousing are considered to be the independent variables. Trade being carried out at ports and by means of seaway transportation is one of the fundamental elements that have a direct impact on the macro-economy of any land and is one of the factors bearing upon that country's economic development. Within the regression analysis, it was found that total burden exports and imports and ship visits correlate highly with the gross national incomes of the urban centers. On the other hand, the assumption that port size, number of workers and stock capacity are related to gross national income is incorrect. 
International Journal of Economics, Business and Accounting Research (IJEBAR)

Peer Reviewed - International Journal

Vol-4, Issue-2, 2020 (IJEBAR)

E-ISSN: 2614-1280 P-ISSN 2622-4771

https://jurnal.stie-aas.ac.id/index.php/IJEBAR

\section{Overview of the Iraqi maritime:}

Iraq is bordered by six countries. Kuwait and Saudi Arabia in the south, Syria and Jordan to the west, Turkey to the north and Iran to the east. However, it has a short coastline of about 48 kilometers lying between the national boundaries of Iran and Kuwait, with all its ports situated within the Al- Basra Province ((G.C.I.P.), 2012).

Iraq has two oil terminals and four commercial ports, Almaqil, Khor Alzubayr, Abu flous and Umm Qasr Port which is the biggest foreign trade port in Iraq. The ports are a crucial link in Iraq's economy as they are a transit point for oil being shipped out to the Persian Gulf and for imports.

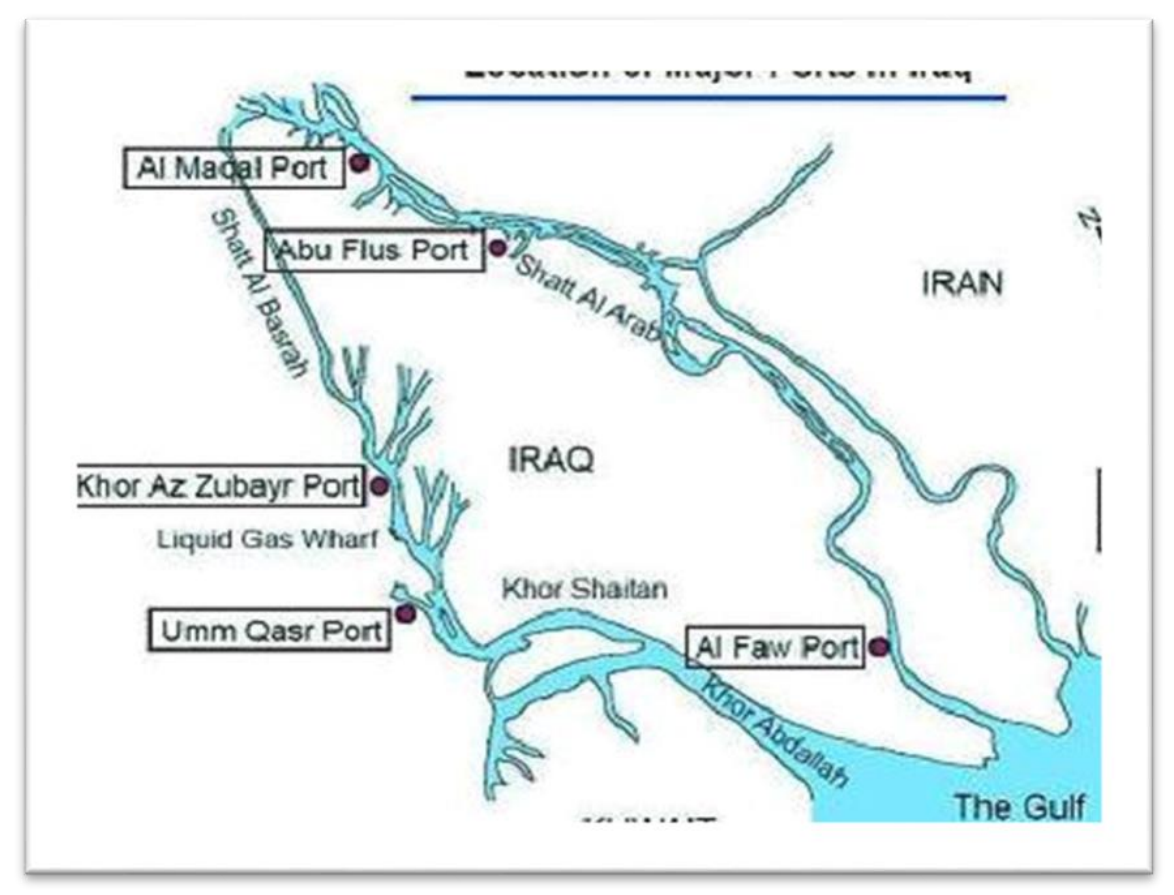

Source: (Visser, 2011).

Figure 1: Map of Iraqi Ports

Commercial ports in Iraq play a prominent role in foreign trade. Data indicates that the maritime sector provided (300) million US\$ in 2015 and the sector employed approximately 10,500 people (Central Statistics Organization (CSO), 2015). Two companies are responsible for the maritime sector- the first one is the General Company for Ports of Iraq (GCPI), which was established in 1919 and has responsibilities related to ports management, coastal navigation and channel dredging and maintenance.

The headquarters of this company is located in Basrah city and as of 2015, has $(9,704)$ workers. The second one is the Iraqi State Company for Maritime Transport (ISCMT), which was established in 1952, and it is responsible for maritime shipping, maritime agency, and national maritime shipping. The headquarters of this company is located in Baghdad and has a branch in Basrah. In 2015 it retained 1,787 employees responsible for management and operations (Iraqi Ministry of Transportation, 2011). Iraq has four commercial ports and two platforms for oil loading, numerous berths in commercial ports (48), with a capacity of 17.5 million tonnes per year, and works them effectively. Additionally, there are jetties (43) with a holding capacity of up to 15.9 million tonnes per year. The following table shows the Iraqi commercial ports, the capacity available, the number of births to each port and depths available to it.

Page 98 International Journal of Economics, Business and Accounting Research (IJEBAR) 
International Journal of Economics, Business and Accounting Research (IJEBAR)

Peer Reviewed - International Journal

Vol-4, Issue-2, 2020 (IJEBAR)

E-ISSN: 2614-1280 P-ISSN 2622-4771

https://jurnal.stie-aas.ac.id/index.php/IJEBAR

Table 1: Iraqi Commercial Ports and characteristics

\begin{tabular}{|l|l|l|l|l|}
\hline Port & $\begin{array}{l}\text { Available } \\
\text { Capacity } \\
\text { (Million Tons } \\
\text { Annually) }\end{array}$ & $\begin{array}{l}\text { Number of } \\
\text { docks }\end{array}$ & $\begin{array}{l}\text { Number of } \\
\text { docks operating }\end{array}$ & $\begin{array}{l}\text { Available depths } \\
\text { at docks } \\
\text { (Meters) }\end{array}$ \\
\hline Al-Maqal Port & 1.5 & 11 & 6 & $6-8$ \\
\hline Umm Qasr Port & 7.5 & 22 & 22 & $6-10$ \\
\hline $\begin{array}{l}\text { Khor Al-Zubair } \\
\text { Port }\end{array}$ & 6.4 & 12 & 12 & $3-8$ \\
\hline Abu Flous Port & 0.5 & 3 & 3 & 6 \\
\hline Total & 15.9 & 48 & 43 & \\
\hline
\end{tabular}

Source: (Ministry of Planning, 2014)

Shatt al-Arab is considered the only maritime canal of Iraq on the Persian Gulf where ships were anchored because of the bombing of artillery and aircraft during the many wars that have passed through the province of Basra, the most important of which was the Iraq-Iran war (1980-1988), and subsequently, the raids of the international coalition during the first Gulf war 1991 and second Gulf war of 2003.Economic sanctions imposed on Iraq and the damage to ports during the most recent war, has rendered the port machinery and equipment is obsolete and much of it is nonoperational. The war also increased the number of sunken vessels in shipping lanes and a halt to the dredging of these lanes. This has, in turn, led to reduced depths in the lanes and off port docks. The sunken vessels hinder ship entry and dredging and maintenance operations. All these factors have had a negative impact on the performance and efficiency of commercial ports and docks (Ministry of Planning, 2014).

The process of lifting the gullies facilitates navigation, back and forth, in the Shatt alArab waters to commercial vessels and oil tankers. Where navigational sources indicate sunken marine parts and the deterioration of the depths of some navigational channels due to the accumulation of mud deposits, is one of the most important challenges faced by the General Company of Iraqi Ports since 2003. Although the company has managed to lift dozens of boats and has spent millions of dollars on the re-drilling of navigational channels and furnishing the buoys guidance, global insurance companies continue to impose large premiums on commercial ships that enter Iraqi ports. The efficiency of maritime facilities in Iraq has dramatically dropped because of the lengthy Iraq-Iran war (1980-1988), the first and second Gulf war, and suspension of new investment due to economic sanctions (1991-2003). As a result, more than three-quarters of imported commodities rely heavily on inland transportation through neighboring countries.

The four main commercial ports in Iraq are as follows:

1. Umm Qasr Port (UQP): located on the line length (12-57-47) to the east and latitude (30/01/40) in the north. The southern end of the Khor Al-Zubair meets with Khor Abdullah, and it is 75 kilometers from the entrance of the city of Basrah. It began operating in 1919 with three berths, expanded to nine berths in 1960, and then increased to 15 berths in 1968 . Now, it is a hub for transporting goods and humanitarian aid to other parts of the country as it is Iraq's only deep-water port and consists of three separate ports, known as Umm Qasr South Port, Umm Qasr North Port and Umm Qasr Mid. Umm Qasr reopened to commercial traffic in June 2004, after decades of war and sanctions left the port idled and in disrepair. It now bustles, with 12,000 workers unloading as many as 40 ships a day. It has become the largest and most important commercial port in Iraq. It consists of two old sidewalks, eight piers, new sidewalks, thirteen guestrooms, pier guestrooms and a preparation port for different receivers of general cargo, which includes containers, grain, sulfur and travelers. While there is 
International Journal of Economics, Business and Accounting Research (IJEBAR)

Peer Reviewed - International Journal

Vol-4, Issue-2, 2020 (IJEBAR)

E-ISSN: 2614-1280 P-ISSN 2622-4771

https://jurnal.stie-aas.ac.id/index.php/IJEBAR

designed capacity for sidewalks totaling at around ( 8.85 million tonnes per year), there is only storage capacity of approximately (614 thousand tonnes per year).

2. Khor Al-Zubair port (KZP): is the second largest commercial port after (UQP) which lies 60 kilometres south of Basrah city center and (105) kilometers from the north end of the Arabian Gulf. The port contains two specialized, reinforced concrete wharves and iron tubular piles designated to the steel plant. Also present are two adjacent, similarly built wharves equipped with two cranes with the capacity to hold up to 15-tonnes, particularly intended to be used for moving iron ore. There are also five specialized wharves for exporting sponge iron up to $250 \mathrm{~m}$ in length with especially equipped sheds to store urea and phosphate and with the required conveyor belts and stacker recliner to discharge them. Finally, there are three steel jetties for general cargo up to 180 meters in length with 12 electrical cranes and pared yards for storage with roadways for vehicles and railways ((GCIP), 2018).

3. Abu Flous Port (AFP): The port is located in Shatt al-Arab- on its western bank, about 20 kilometers from the center of the southerly province of Basra. The port consists of three steel berths and piers each measuring 75 meters long and 18 meters wide. The front end of the port is (525) meters in length and there are three electric cranes with five- tonnecapacity each on each pier and besides that, yards which were established to build the storehouses 75 meters in length and 33 meters in width (Iraqi Ministry of Transportation, 2011).

4. Rehabilitation of berth number one has not yet been implemented. However, rehabilitation of berth number two and a part of berth number three have been finished and are now in service for port operations.

5. Al-Maqal Port (MP): Founded in 1919 as the first port in Iraq is located on the banks of the Shatt al-Arab, just 135 kilometers from the northern end of the Persian Gulf. The front end of the piers measure (2.5) kilometers, allowing Marina ships a length of 500 meters to dock. In addition to the port there are 12 berths on the quay totaling up to 4,000 square meters in size and the docks include 45 electric cranes and 25 shed and stores with differing sizes(Iraqi Ministry of Trnsportation, 2018).

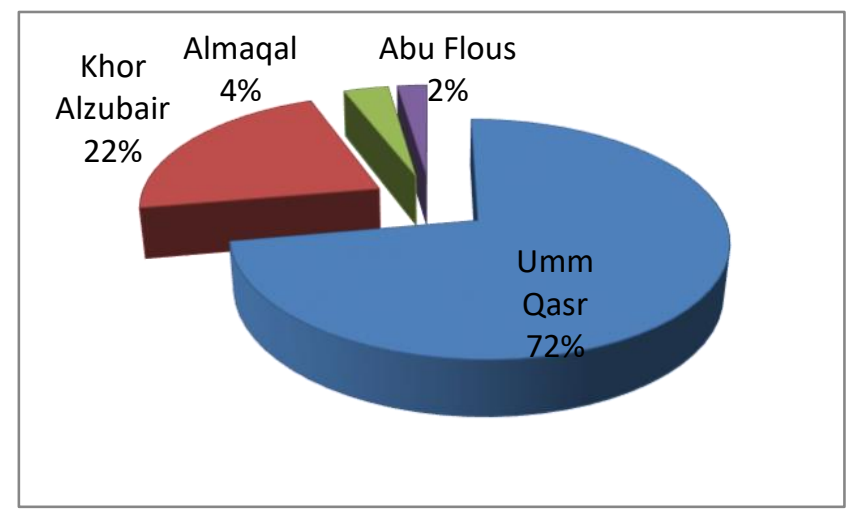

Figure 2: Percentage of goods imported through Iraqi ports by port for 2015 Source:(Central Statistical Organization(CSO), 2015)

Figure 2 shows that Umm Qasr port has the biggest share of goods imports (72\%), then followed by Khor Al-Zubair (22\%) and Abu Flous with the smallest share (2\%).

After 2003, as a result of the unstable security situation, the inefficiency of Iraqi ports and the difficulty receiving masses of goods, a large percentage of goods were directed to Jordan and Turkey as shown in table 2 .

Page 100 International Journal of Economics, Business and Accounting Research (IJEBAR) 
International Journal of Economics, Business and Accounting Research (IJEBAR)

Peer Reviewed - International Journal

Vol-4, Issue-2, 2020 (IJEBAR)

E-ISSN: 2614-1280 P-ISSN 2622-4771

https://jurnal.stie-aas.ac.id/index.php/IJEBAR

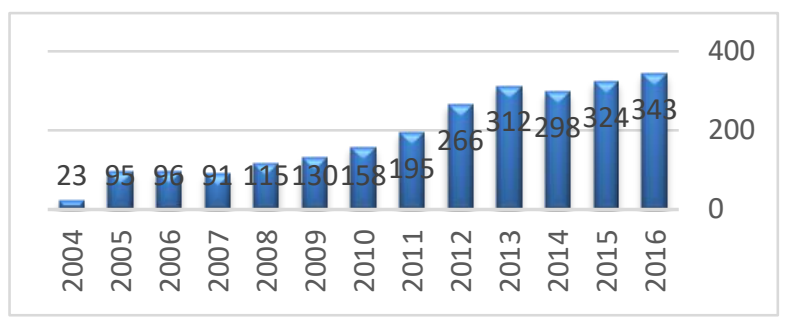

Table 2: Number of containers from Jordan and Turkey to Iraq, and those handled at ports of Iraq.

\begin{tabular}{|c|c|c|c|c|}
\hline Year & $\mathbf{2 0 0 4}$ & $\mathbf{2 0 0 9}$ & $\mathbf{2 0 1 0}$ & $\mathbf{2 0 1 1}$ \\
\hline $\begin{array}{c}\text { Number of containers from } \\
\text { Jordan (BOX) Share (\%) }\end{array}$ & $\begin{array}{c}40000 \\
(35 \%)\end{array}$ & $\begin{array}{c}51525 \\
(24 \%)\end{array}$ & $\begin{array}{c}39046 \\
(16 \% 0\end{array}$ & $\begin{array}{c}54567 \\
(21 \%)\end{array}$ \\
\hline $\begin{array}{c}\text { Number of containers from } \\
\text { Turkey (BOX) Share (\%) }\end{array}$ & $\begin{array}{l}57000 \\
(49 \%)\end{array}$ & $\begin{array}{c}71168 \\
(33 \%)\end{array}$ & $\begin{array}{c}74399 \\
(30 \%)\end{array}$ & $\begin{array}{l}77777 \\
(30 \%)\end{array}$ \\
\hline $\begin{array}{c}\text { Containers handled at ports } \\
\text { in Iraq (BOX) Share (\%) }\end{array}$ & $\begin{array}{c}18000 \\
(16 \%)\end{array}$ & $\begin{array}{c}90525 \\
(43 \%)\end{array}$ & $\begin{array}{c}133508 \\
(54 \%)\end{array}$ & $\begin{array}{c}124934 \\
(149 \%)\end{array}$ \\
\hline
\end{tabular}

Source: (General Company for Ports of Iraq (GCPI), 2015).

Table 2 shows that the number of containers handled at Iraqi ports increased from $16 \%$ in 2004 to $49 \%$ in 2011, this is due to the rehabilitation of Iraqi ports and improvements in the security situation in southern Iraq. Concurrently, containers from Jordan declined from 35\% to $21 \%$, and from Turkey, containers also declined from $49 \%$ to $30 \%$.

4. The economic role of Iraqi Ports:

Iraqi commercial ports play a limited role in economic development due to several factors. The most significant being the dependence on oil, which accounts for more than two-thirds of its GDP (95\%), of government revenues, and (99\%) of its total exports (IMF, 2013,14), as well as ports having low capacity and the lack of advanced systems used in the management of said ports.Although total port revenues have increased significantly from 2004 to 2016, as shown in figure 3 , they still do not make a significant contribution to the country's total public revenues. For example, port revenues for 2016 totaled 343 million US\$, while total revenues for Iraq in the same year, were about 68 billion US\$.

Figure 3: Total Annual Revenues of Iraqi Ports (2004-2016) (Million US\$)

Source: (Central Statistics Organization (CSO), 2017).

Figure 3 shows that total revenues rose continuously from 2007 until 2013 and decreased in 2014 due to the two major crises that affected the Iraqi economy. These were the sharp 
International Journal of Economics, Business and Accounting Research (IJEBAR)

Peer Reviewed - International Journal

Vol-4, Issue-2, 2020 (IJEBAR)

E-ISSN: 2614-1280 P-ISSN 2622-4771

https://jurnal.stie-aas.ac.id/index.php/IJEBAR

decline in international oil prices and the invasion by the terrorist organization ISIS into some Iraqi provinces in the west and northwest of Iraq. Nonetheless, these numbers explain the limited role of ports in economic development, for example, in 2013, total revenue reached the maximum with 310 Million US\$ while the total revenue of Iraqi budget for the same year was 99.41 Billion US\$, which means the ports total revenue accounted for only $0.31 \%$ of the total revenue of the Iraqi budget.

The same applies to the number of workers in the port sector, which in 2016, amounted to a total of 19,839 workers that were registered in the General Company of the ports of Iraq and the General Company for Maritime Transport. This number is fairly insignificant when held up against the number of employees in the Iraqi public sector which stood at about 4 million (Central Statistics Organization (CSO), 2018).

\section{The main challenges of Iraqi maritime sector:}

The development of the Iraqi maritime sector, until recently, has been exclusively the responsibility of the central government with the private sector playing no role in the matter at all, but because of its heavy dependency on oil, this sector is facing many challenges such as:

1. Chaos and corruption. Chaos, due to the multiplicity of security agencies and of references that control their work- there are nine parties that assume the functions of security and monitoring without these entities having institutional affiliations with the General Ports Company. Corruption includes the counterfeiting of numbers, types, and weights of cargo that arrive at the ports, generally in order to reduce or evade taxes through bribing the relevant employees, as well as, the forgery of official documents, such as invoices, certificates of origin, certificates of standardization and quality control. This reduces port revenues and effectiveness. The Iraqi Integrity Commission announced the capture of 14 containers full of medicines which entered the country with forged documents and without the approval of the Iraqi Health Ministry. Over the past few years, several reports have been published in the Iraqi local press on the smuggling of materials from ports without official permits or papers.

2. Limited financial allocations are another big challenge, which reflects shortages in marine equipment (ships, cranes, lighting ships, excavators, pollution control ports, and water and fuel tankers). For example, the investment allocation was about 33 million US\$ in 2014 which represents (2\%) of the transport sector allocation, and low incomarison to previous years.

Table 3: Investment customization of ports (Million US\$) (2004-2014)

\begin{tabular}{|c|c|c|c|c|c|c|}
\hline Year & 2004 & 2006 & 2008 & 2010 & 2012 & 2014 \\
\hline $\begin{array}{c}\text { Investment customization } \\
\text { of ports (Million US\$) }\end{array}$ & 9 & 43 & 53 & 44 & 49 & 33 \\
\hline $\begin{array}{c}\text { Investment customization } \\
\text { of port to Whole transport } \\
\text { sector (\%) }\end{array}$ & 4 & 41 & 21 & 12 & 9 & 2 \\
\hline
\end{tabular}

Source: (Iraqi Ministry of Transportation, 2016).

3. The Iraqi ports face stiff competition from nearby countries such as the United Arab Emirates, Qatar, and Kuwait. These ports have made significant progress during the past two decades, at the same time, the performance and efficiency of Iraqi ports has declined due to the enforcement of economic sanctions. 
International Journal of Economics, Business and Accounting Research (IJEBAR)

Peer Reviewed - International Journal

Vol-4, Issue-2, 2020 (IJEBAR)

E-ISSN: 2614-1280 P-ISSN 2622-4771

https://jurnal.stie-aas.ac.id/index.php/IJEBAR

4. Absence of, or weak participation of the private sector, due to national legislation, expels investments that lead to ship owners registering their ships in open registration countries. This results in the private sector playing a major role in constructing and operating some port infrastructure, as well as providing services. It is possible to open the door to the private sector to run basic container docks. If the private sector is reluctant to participate in constructing infrastructure, the state should intervene rather than leaving the matter pending. It should then open the door to the private sector in the fields of operation and service provisions, along with allowing contributions from the banking sector in facilitating approvals and financing procedures directed at shipbuilding. Investments in this sector are classified as long-term and high-risk which, in turn, is problematic.

5. Restrictions on administrative and bureaucratic procedues which require the acquisition of many licenses, as well as a lengthy wait for the release of goods and therefore, additional costs incurred by the exporters.

6. Iraq is not on the White List, which is a list of countries assessed by the International Maritime Organization as properly implementing the Standards of Training, Certification and Watchkeeping of Seafarers (STCW). Conventions and a country which is not on the "White List" do not invalidate its certificates or endorsements. STCW certificates and endorsements belonging to countries not on the "White List" remain valid. However, port state control is not likely to accept these documents at face value. They may detain vessels until ship owners can establish, by other means, that each crew member is in compliance with STCW 95. As a practical matter, to avoid detentions, ship owners will be reluctant to hire mariners who do not possess certificates or endorsements from "White List" countries (The Seamen's Church Institute, 2016).

All these obstacles have led Iraq to be at the bottom of The Logistic Performance Index (LPI)- see table 4, which is published by the World Bank, the first version of which was published in 2007 and has since been updated every two years. This index has a scoring system ranging between (1-5) points, (1) being the worst and (5), the best, and it includes six indicators to analyze countries (The World Bank, 2016b):

1. The quality of trade and transport infrastructure.

2. The ease of arranging competitively priced shipments.

3. The competence and quality of logistics services.

4. The ability to track and trace consignments.

5. The frequency with which shipments reach consignees.

6. Scheduled or expected delivery times.

Table 4: The Rank of Iraq and Arabian Countries in the Logistic Performance Index 2016

\begin{tabular}{|l|l|l|l|l|l|l|l|}
\hline Country & $\begin{array}{c}\text { LPI } \\
\text { Rank }\end{array}$ & Customs & Infrastructure & $\begin{array}{c}\text { International } \\
\text { Shipments }\end{array}$ & $\begin{array}{c}\text { Logistics } \\
\text { quality and } \\
\text { competence }\end{array}$ & $\begin{array}{c}\text { Tracking } \\
\text { and } \\
\text { tracing }\end{array}$ & $\begin{array}{l}\text { Time } \\
\text { lines }\end{array}$ \\
\hline UAE & 13 & 12 & 13 & 7 & 18 & 18 & 18 \\
\hline Qatar & 30 & 21 & 28 & 26 & 29 & 35 & 35 \\
\hline Bahrain & 44 & 45 & 48 & 41 & 33 & 44 & 51 \\
\hline Oman & 48 & 61 & 34 & 40 & 38 & 57 & 57 \\
\hline Egypt & 49 & 65 & 50 & 45 & 43 & 45 & 48 \\
\hline $\begin{array}{l}\text { Saudi } \\
\text { Arabia }\end{array}$ & 52 & 68 & 40 & 48 & 54 & 49 & 53 \\
\hline Kuwait & 53 & 56 & 56 & 24 & 70 & 53 & 55 \\
\hline
\end{tabular}

Page 103 International Journal of Economics, Business and Accounting Research (IJEBAR) 
International Journal of Economics, Business and Accounting Research (IJEBAR)

Peer Reviewed - International Journal

Vol-4, Issue-2, 2020 (IJEBAR)

E-ISSN: 2614-1280 P-ISSN 2622-4771

https://jurnal.stie-aas.ac.id/index.php/IJEBAR

\begin{tabular}{|l|l|l|l|l|l|l|l|}
\hline Jordan & 67 & 83 & 62 & 49 & 61 & 62 & 71 \\
\hline Algeria & 75 & 108 & 80 & 77 & 59 & 72 & 91 \\
\hline Lebanon & 82 & 66 & 74 & 75 & 108 & 78 & 111 \\
\hline Morocco & 86 & 124 & 90 & 54 & 91 & 122 & 83 \\
\hline Sudan & 103 & 122 & 126 & 100 & 118 & 104 & 75 \\
\hline Tunisia & 110 & 147 & 93 & 133 & 90 & 84 & 99 \\
\hline Libya & 137 & 153 & 142 & 123 & 101 & 153 & 113 \\
\hline Iraq & 149 & 139 & 153 & 134 & 150 & 149 & 135 \\
\hline Syria & 160 & 160 & 160 & 160 & 160 & 138 & 147 \\
\hline
\end{tabular}

Source: (The World Bank, 2016a).

Table 4 shows that Iraq had the second worst ranking among Arab countries after Syria as of 2016, scoring just (2.14) points, which, at its maximum, represents (35.6\%) of its performance. This score is less than the world average, which is (2.88) points.

The worst results are in infrastructure indicators, then logistics quality and then competence indicator.

During the five editions of LPI, Iraq's rank did not evolve positively. The best rank was in 2014 which was (144) among 163, then in 2016 went down to (149), as shown in table 5:

Table 5: Iraq's rank in five editions of LPI

\begin{tabular}{|c|c|c|}
\hline Year & Rank & Score \\
\hline 2007 & Not included & - \\
\hline 2010 & 151 (among 158 countries) & 2.11 \\
\hline 2012 & 148 (among 158 countries) & 2.16 \\
\hline 2014 & 144 (among 163 countries) & 2.30 \\
\hline 2016 & 152 (among 160 countries) & 2.15 \\
\hline
\end{tabular}

Source:(The World Bank, 2016a).

Iraq's low rank in the LPI over the years illustrates the fact that the Iraqi government has not make the required efforts to develop the performance of Iraqi ports and improve their productivity indicators.

\section{Future of Iraqi Ports}

To develop the maritime sector and enhance its role in economic development, there are two major courses of action, the first one is implementing the Al-Faw Grand port, and the second is developing the current ports especially Um-Qasr.

1. Al-Faw Grand Port: In April 2010, the Iraqi Ministry of transport laid the foundation stone of the Al-Faw grand port project on the Gulf in the south of the country near Basrah city. The port, by design, has the core container terminal length of 39 thousand meters and a berth length of 2000 meters, as well as, an arena for containers with an area of more than one million $\mathrm{m}_{2}$ and another arena with a multi-purpose area of 600 thousand $\mathrm{m}_{2}$ with an absorptive capacity of 99 million tonnes annually. Total cost for the establishment reaches 4.4 billion Euros and will hopefully connect that port with a railway line linking the Gulf with Turkey and Northern Europe through Iraq. This project is known as " The Dry Canal" (Ghassan et al., 2015), and would be the largest infrastructure project in Iraq in the last 30 years. Aims are to fund Iraqi and foreign countries, both public and private. The construction cost of the Port has been estimated to be US\$6.1 billion US. GCPI started the construction of the eastern breakwater and dredging of the access navigation channel.

The establishment of the port will contribute to the following benefits:

a. Relieve the pressure on the existing ports. 
International Journal of Economics, Business and Accounting Research (IJEBAR)

Peer Reviewed - International Journal

Vol-4, Issue-2, 2020 (IJEBAR)

E-ISSN: 2614-1280 P-ISSN 2622-4771

https://jurnal.stie-aas.ac.id/index.php/IJEBAR

b. Meet the country's export and import needs.

c. Provide thousands of jobs

d. Act as a starting point for Iraq's dry channel linking Asia, Europe, Turkey, and Syria. The use of Iraq as a dry channel for the transport of goods between Asia and Europe is expected to reach 110 million tonnes at the end of the project.

e. Diversify the Iraqi economy to decrease reliance on the oil sector.

Table 6 : Feasibility Study of the Al-Faw Grand Port: Traffic demand forecast (Million Tons)

\begin{tabular}{|l|l|l|l|}
\hline & $\mathbf{2 0 1 8}$ & $\mathbf{2 0 2 8}$ & $\mathbf{2 0 3 8}$ \\
\hline Container & 24.0 & 40.0 & 70.0 \\
\hline Dry Bulk total & 24.0 & 32.0 & 44.0 \\
\hline $\begin{array}{l}\text { - Wheat } \\
\text { - Other dry }\end{array}$ & 17.1 & 23.5 & 33.0 \\
\hline
\end{tabular}

Source: (Group of Italian Companies (C.I.I.T.I), 2008).

Table 6 shows that the containers demand would have increased from 24 million tonnes to 70 million tonnes in the year 2038, only if the construction had started in 2015. However, this did not happen because of the double crises that hit the Iraqi economy in mid-2014, which were, the sharp decline in international oil prices and invasion of ISIS to some of the Iraqi provinces in the north and north east of the country. These two occurrences caused a sharp decline in financial revenues which prevented the implementation of the Grand Port. If the port implementation had occurred at the expected time, then revenues would have been as follows.

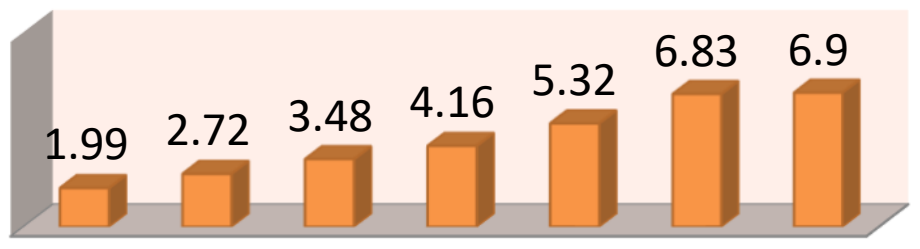

2018202220262030203420382040

Figure 4: Expected revenues of Al-Faw Grand Port (2018-2040) (Billion US\$) Source: (Group of Italian Companies (C.I.I.T.I), 2008). 
International Journal of Economics, Business and Accounting Research (IJEBAR)

Peer Reviewed - International Journal

Vol-4, Issue-2, 2020 (IJEBAR)

E-ISSN: 2614-1280 P-ISSN 2622-4771

https://jurnal.stie-aas.ac.id/index.php/IJEBAR

This port would bring large amounts of financial revenue to the Iraqi economy and would enhance the share of the transport sector in GDP and state budget, also, it would help diversify the economy.

The Italian study of Iraq's comprehensive transport plan for 2005 indicated that the construction of the Faw Grand Port would create thousands of jobs starting from 70,000 in 2018 to 85,000 in 2024 (Italian Consortium for Iraqi Transport Infrastructure, 2005).

2. Develop the current ports: The Iraqi government plan for (2013- 2017) indicated the goals of port development as shown in table 7:

Table 7: Goals of port development in Iraqi National Development Plan (2013-2017)

\begin{tabular}{|c|c|c|c|c|c|}
\hline Name of port & \multicolumn{2}{|c|}{2013} & $\begin{array}{c}\text { Berth required } \\
(2013-2017)\end{array}$ & \multicolumn{2}{c|}{2017} \\
\hline & $\begin{array}{c}\text { Number } \\
\text { of births }\end{array}$ & $\begin{array}{c}\text { Capacity } \\
(1000 \\
\text { t/Yr })\end{array}$ & & $\begin{array}{c}\text { Number } \\
\text { of births }\end{array}$ & $\begin{array}{c}\text { Capacity } \\
(1000 \\
\text { t/Yr })\end{array}$ \\
\hline Um Qasr & 22 & 7500 & 19 & 41 & 14000 \\
\hline Khor Al-Zubair & 12 & 6400 & 13 & 25 & 10650 \\
\hline Maqal & 9 & 2250 & 5 & 14 & 3600 \\
\hline Abu Flus & 3 & 500 & - & 3 & 750 \\
\hline Total & 46 & 16650 & 37 & 83 & 29000 \\
\hline
\end{tabular}

Source: (Ministry of Planning, 2013)

Table 7 shows that in 2017 the number of berths rose from 46 in 2013 to 83 in 2017, which indicates a rise of $180 \%$ and this rise lead the capacity to increase from 16,650 (1000 $\mathrm{t} / \mathrm{yr})$ in 2013 to 29,000 (1000 t/yr) in 2017. Um Qasr port takes the biggest share in this rise with $186 \%$, in number of berths and capacity.

In April 2014, International Container Terminal Service Inc. (I.C.T.S.I), signed a contract with General Company for Ports of Iraq to operate, develop, and expand the container handling facilities at the Ports of Umm Qasr in Iraq. ICTSI will manage, operate and rehabilitate the port's existing facility at Berth 20 and build a new container and general cargo terminal. The 10-year concession covers Berth 20, while a 26-year concession agreement covers the new container terminal under the expansion component of the project. The investment program is designed to complement the increasing use of the southern port of Umm Qasr, resulting in growing trade flows of container, general and project cargo traffic as well as aid cargoes, and the expectation of users for congestion-free access to terminal facilities operated in accordance with international, best standard practices.

To meet the demand forecasted, it is imperative to improve the performance of cargo handling, capacity of present terminals, and to acquire new terminals. UQP is the main container port in Iraq, which handles the largest share of container cargo in Iraq. If port development of Al-Faw grand port is delayed, UQP would need to handle all container cargo in Iraq, but if the new port opens earlier, UQP wouldn't need to develop so extensively for container handling. Taking these points into consideration, the Ministry of Transport has put in place two options to develop and expand the capacity of Um- Qasr and Khor Al-Zubair ports as follows:

a. Construction of (13) multipurpose berths in Um-Qasr with the designed capacity of $(3,750,000)$ tonnes with costs of about (500) Million US\$. This project is an integral part of the existing berths in Umm Qasr port and aims to increase the loading and unloading capacity of the goods in the port by establishing (13) berths for multi-purpose containers with all accessories, equipment, services, service buildings, sheds, towers, railways, internal roads, some container berths and specialized berths covering an area of 151,773 $\mathrm{m} 2$.

Page 106 International Journal of Economics, Business and Accounting Research (IJEBAR) 
International Journal of Economics, Business and Accounting Research (IJEBAR)

Peer Reviewed - International Journal

Vol-4, Issue-2, 2020 (IJEBAR)

E-ISSN: 2614-1280 P-ISSN 2622-4771

https://jurnal.stie-aas.ac.id/index.php/IJEBAR

b. Construction of (13) berths in the multi-purpose port of Khor Al-Zubair with the designed capacity of $(4,250,000)$ tonnes which will cost about $(500)$ Million US\$. Due to the limited capacity of the berths in the port, the establishment of flat concrete berths based on ferrous pipes has been proposed, as well as, four docks for containers with buildings and services. The project includes the construction of 13 berths for multi-purpose containers with all their requirements covering an area of $150,740 \mathrm{~m} 2$ south of the berths of Khor AlZubair Port. This will increase the handling capacity of the sidewalks where currently (4) million tonnes / year is managed and the expansion of these sidewalks leads to doubling port power.

At the present time, and because of the financial crisis experienced by the Iraqi economy as a result of low oil prices and high proportion of operational expenditures in the state budget, the second option is preferable. In addition, planning to implement the first option at the earliest opportunity, either through government investment or private investment local or foreign, is urgently needed to stimulate the economy, achieve economic diversification and create thousands of jobs.

\section{Closing}

\subsection{Conclusion}

The various troubles and obstacles faced by the ports of Iraq, which have piled up over the last three decades, are a major factor in its underdevelopment and weakened its functional capacity. This period just so happened to coincide with major developments in international ports, which were able to develop a number of new generations of ports while Iraq's ports were unable to function on preceding generations.

Due to underdevelopment and impaired functional capacity, Iraqi ports have had a very limited role in economic development. Iraq will face an increasing demand of imports and exports in the coming years, estimated at 53 million tonnes in 2018 and therefore the current capacity of Iraqi ports, at 15.9 million tonnes, could not meet this demand. The establishment of the Al-Faw grand port will have different developmental effects on the Iraqi economy to contribute significantly to the diversification of the economy. The current situation at Iraqi ports would lead to shortage of port facilities and queues of waiting ships in the near future.

\subsection{Suggestions}

1. Activate the current commercial ports and raise their capacity through the use of modern technology in shipping and logistics. Increasing the investment allocation for ports in the Iraqi Federal Budget and implementing the National Strategy to develop ports, which reduces waiting times, as well as reducing administrative and bureaucratic procedures.

2. Develop an integrated strategy accompanied by strong political will to minimize corruption in the ports sector, thereby maximizing revenues.

3. Emphasize the importance of speeding up the establishment of the port of Al-Faw through the monitoring of budget allocated to it in the state budget and accelerate the implementation of the dry canal to connect the port to Europe through Turkey.

4. Build strategic alliances with several international ports as part of ports development, and increase its efficiency, transfer advanced engineering to these major ports to be attractive. This would lead to a step-up in productivity along with improvements in efficiency through the private sectors management skills and improvement of port management as an indispensable precondition for the further growth of the maritime shipping and ports sector in Iraq. Overall, strengthen the private sector's role in implementing, operating and providing port services. 
International Journal of Economics, Business and Accounting Research (IJEBAR)

Peer Reviewed - International Journal

Vol-4, Issue-2, 2020 (IJEBAR)

E-ISSN: 2614-1280 P-ISSN 2622-4771

https://jurnal.stie-aas.ac.id/index.php/IJEBAR

5. It is important for restoration and efficient management of Iraqi ports, not only to improve port facilities physically, for example, repair damaged facilities, develop facility shortages or remove obstacles, but also to raise efficiency, improve and modernize management and operational systems of ports. In particular, the lack of proper Information Technology (IT) Systems at Iraqi ports brings capacity constraints and major operational obstructions. With this in mind, GCPI carried out a study to introduce IT systems to UQP North as a part of a pilot scheme, aiming at improving and modernizing the management and operation systems in the port sector.

\section{References}

(G.C.I.P.), G. C. I. P. (2012). Data Collection Survey on Port Sector Development Plan. Ministry of Planning, baghdad.

(GCIP), G. C. I. P. (2018). Data Collection Survey On Port Sector Development Plan In Iraq. Minsitry of Planning.

Central Statistical Organization(CSO). (2015). Statistical of Water Transport Activities in State Sector. Ministry of Planning, Baghdad.

Central Statistics Organization (CSO). (2015). Statistics of state companies in maritime sector 2015. Ministry of Planning, Baghdad.

Central Statistics Organization (CSO). (2017). Transport indicators. http://www.cosit.gov.iq/ar/2013-03-29-08-38-49

Central Statistics Organization (CSO). (2018). Indicators of employment and Unemployment. http://cosit.gov.iq/ar/2013-01-31-08-48-55

Cipolla, C. M. (1978). The economic history of world population. Harvester Press Brighton.

Dwarakish, G. S., \& Salim, A. M. (2015). Review on the Role of Ports in the Development of a Nation. Aquatic Procedia, 4(1), 295-301.

General Company for Ports of Iraq (GCPI). (2015). MASTER PLAN STUDY FOR PORT SECTOR IN THE REPUBLIC OF IRAQ FINAL REPORT. http://open_jicareport.jica.go.jp/pdf/12248399_01.pdf

Ghassan, B., Abdul, H., \& Corresponding, H. (2015). The Dry Canal Project ; An Overview for a Land -based New Connection over Iraq for the International Commercial Transportation. 7(6).

Group of Italian Companies (C.I.I.T.I). (2008). Feasibility Study of the New Basrah Grand Port. Italy.

Iraqi Ministry of Transportation. (2011). Annual report. Baghdad.

Iraqi Ministry of Transportation. (2016). Investment Allocation of Transport Sector. Baghdad. Iraqi Ministry of Trnsportation. (2018). Almaqal Port.

Italian Consortium for Iraqi Transport Infrastructure. (2005). Transport Plan Evaluation \& Programming, Phase 2.

Merk, O. (2010). The Competitiveness of Global Port-Cities | OECD READ edition. 184. https://doi.org/10.1787/9789264205277-en

Ministry of Planning. (2013). National Development Plan (2013-2017). January 2013.

Ministry of Planning. (2014). National Development Plan for the Years 2010-2014. Ministry of Planning.

Stopford, M. (1997). Maritime Economics Second Edition. https://doi.org/10.1016/S09666923(98)00021-0

The Seamen's Church Institute. (2016). IMO white list. https://seamenschurch.org/article/imo-white-list

The World Bank. (2016a). Connecting to Compete. Washington.

The World Bank. (2016b). Trade Logistic in the Global Economy. https://www.worldbank.org/en/news/feature/2016/06/28/connecting-to-compete2016-trade-logistics-in-the-global-economy

Page 108 International Journal of Economics, Business and Accounting Research (IJEBAR) 
International Journal of Economics, Business and Accounting Research (IJEBAR)

Peer Reviewed - International Journal

Vol-4, Issue-2, 2020 (IJEBAR)

E-ISSN: 2614-1280 P-ISSN 2622-4771

https://jurnal.stie-aas.ac.id/index.php/IJEBAR

United Nations Conference on Trade and Development - Recent developments and trends in international maritime transport affecting trade of developing countries, (2013).

Visser, R. (2011). Kuwait Port Project Makes Waves in Iraqi Politics. https://merryabla64.wordpress.com/2011/05/21/kuwait-port-project-makes-wavesin-iraqi-politics/ 